\title{
KEBIJAKAN PENGELOLAAN PAJAK DAERAH DALAM KERANGKA PENYELENGGARAAN OTONOMI DAERAH \\ (Analisa Terhadap Implementasi Wewenang Pengelolaan Pajak Daerah Oleh Pemerintah Pusat Dan Pemerintah Daerah) $)^{\Omega}$
}

\author{
Kadar Pamuji \\ Fakultas Hukum Universitas Jenderal Soedirman Purwokerto \\ E-mail: kadarpamuji@yahoo.co.id
}

\begin{abstract}
Regional autonomy is the right, authority, and duty to regulate autonomous regions and manage their own affairs and interests of local communities in accordance with the legislation. One of which is owned by the local authority is the authority to impose taxes. Supporting local autonomy, the local tax management policies cannot be separated from the regional autonomy policy direction outlined by the Central Government. Local Government as implementing regional autonomy in the management of local taxes tends to be subject to the rules specified by the Central Government. Changes of local tax management policies show that the government has no found raw format in the management of local taxes management yet. Management of local taxes does not show the direction to the actual implementation of regional autonomy due to dominant intervention by the central government.
\end{abstract}

Key words : policy, local taxes, local autonomy

Abstrak

Otonomi daerah adalah hak, wewenang, dan kewajiban daerah otonom untuk mengatur dan mengurus sendiri urusan pemerintahan dan kepentingan masyarakat setempat sesuai dengan peraturan perundang-undangan. Salah satu wewenang yang dimiliki oleh daerah adalah wewenang untuk memungut pajak. Sebagai pendukung otonomi daerah, maka kebijakan pengelolaan pajak daerah tidak terlepas dari arah kebijakan otonomi daerah yang digariskan oleh Pemerintah Pusat. Pemerintah Daerah sebagai pelaksana otonomi daerah dalam pengelolaan pajak daerah cenderung tunduk pada aturan yang sudah ditentukan oleh Pemerintah Pusat. Berubah-ubahnya kebijakan pengelolaan pajak daerah menunjukan bahwa Pemerintah Pusat belum menemukan format baku di dalam pengelolaan pajak daerah. Pengelolaan pajak daerah tidak menunjukan arah kepada pelaksanaan otonomi daerah yang sebenarnya, karena masih banyak campur tangan yang dilakukan oleh Pemerintah Pusat.

Kata kunci : kebijakan, pajak daerah, otonomi daerah

\section{Pendahuluan}

Pemberian otonomi kepada daerah di samping dalam rangka memperhatikan adanya keanekaragaman daerah di Indonesia, juga dimaksudkan untuk memberikan ruang demokrasi, dan partisipasi masyarakat. Peluang dan kesempatan dibuka sangat luas kepada daerah dalam rangka mendukung tujuan pemberian otonomi tersebut,

$\Omega$ Tulisan ini merupakan hasil penelitian Hibah Disertasi Doktor dengan sumber dana dari DIPA Unsoed Tahun 2013 Berdasarkan Surat Perjanjian Pelaksanaan Penelitian Disertasi Doktor Nomor: 2538.14/UN23.10/PN/2013 Tanggal 6 Mei 2013. daerah otonom juga diberi keleluasaan untuk melaksanakan kewenangannya secara mendiri, luas, nyata, dan bertanggung jawab.

Pasal 18 ayat (5) UUD Negara Republik Indonesia Tahun 1945 menyebutkan Pemerintahan Daerah menjalankan otonomi seluas-luasnya, kecuali urusan pemerintahan yang oleh UU ditentukan sebagai urusan Pemerintah. Dengan adanya kebijakan desentralisasi, maka daerah mempunyai kebebasan (vrijheid) untuk mengatur dan mengurus sendiri urusan rumah tangganya. 
Kebijakan yang dilakukan oleh Pemerintah Pusat adalah dengan memberikan wewenang yang luas untuk mengurus rumah tangganya sendiri, termasuk di dalamnya wewenang untuk menggali potensi pemasukan keuangan daerah salah satunya adalah pajak daerah. Pajak adalah iuran rakyat kepada kas negara berdasarkan Undang-Undang (yang dapat dipaksakan) dengan tiada mendapat jasa timbal (kontraprestasi) yang langsung dapat ditunjukkan dan yang digunakan untuk membayar pengeluaran umum. ${ }^{1}$

Pasal 23A UUD Negara Republik Indonesia Tahun 1945 mengamanatkan bawa pajak dan pungutan lain yang bersifat memaksa untuk keperluan Negara diatur dengan Undang-undang (UU). Pelaksanaan amanat Pasal 23A UUD dimuat di dalam Pasal 157 UU Nomor 32 Tahun 2004 tentang Pemerintahan Daerah jo Pasal 5 ayat 2 UU Nomor 33 Tahun 2004 tentang Perimbangan Keuangan Antara Pemerintah Pusat dan Pemerintahan Daerah menyatakan bahwa sumber pendapatan Daerah terdiri dari: Pendapatan Asli Daerah (PAD), Dana Perimbangan, dan lain-lain pendapatan. Pendapatan Asli Daerah (PAD) adalah pendapatan yang diperoleh daerah yang dipungut berdasarkan peraturan daerah sesuai dengan peraturan perundang-undangan, yaitu hasil pajak daerah, retribusi daerah, hasil pengelolaan kekayaan daerah yang dipisahkan serta lainlain PAD yang sah. Jelas tersurat bahwa dalam rangka pelaksanaan otonomi daerah, maka daerah diberi keleluasaan untuk menggali potensi yang dimilikinya dan salah satu potensi tersebut adalah pajak daerah, atau dengan kata lain pajak daerah adalah salah satu sumber pemasukan daerah dalam rangka pelaksanaan otonomi daerah.

Menurut pendapat Sri Hartini bahwa dengan diberlakukannya UU No. 32 Tahun 2004 tentang Pemerintahan Daerah dan UU No. 33 Tahun 2004 tentang Perimbangan Keuangan Pusat dan Daerah, telah menciptakan paradigma yang ber-dampak pada pelimpahan kewenangan

Mardiasmo, 2000, Perpajakan Edisi Revisi, Yogyakarta: Penerbit Andi, hlm. 1

Sri Hartini dan Setiadjeng Kadarsih, "Analisis Terhadap Implementasi Kebijakan Pengelolaan Jalan di Kabupaten Banyumas", Jurnal Dinamika Hukum, Vol. 12, No. 2, Mei 2012, Purwokerto: Fakultas Hukum Unsoed, hlm. 285 dalam perumusan dan pelaksanaan kebijakan di tingkat daerah. ${ }^{2}$ Menurut Nurmayani bahwa konsekuensi logis dari pemberian otonomi kepada daerah adalah juga diikuti dengan memformulasikan model perimbangan keuangan anatara pusat dan daerah secara berimbang agar daerah mampu membiayai pelaksanaan urusan pemerintahan yang menjadi kewenangannya. ${ }^{3}$

Mendasarkan pada amanat Pasal 23A UUD tersebut di atas maka Pemerintah mengeluarkan UU tentang pajak daerah. Beberapa UU pajak daerah yang pernah diberlakukan semenjak masa Orde Baru adalah UU No. 18 Tahun 1997 tentang Pajak Daerah dan Retribusi Daerah yang diundangkan pada tanggal 23 Mei 1997 yang kemudian diubah dengan UU No. 34 Tahun 2000 yaitu UU tentang Perubahan Atas UU Republik Indonesia Nomor 18 Tahun 1997 Tentang Pajak Daerah Dan Retribusi Daerah yang kemudian dicabut dengan UU No. 28 Tahun 2009 tentang Pajak Daerah dan Retribusi Daerah.

Pemerintah Pusat, pada masa berlaku ketiga Undang-undang Pajak Daerah tersebut di atas ternyata telah menerapkan kebijakan yang berbeda-beda. Pemberlakuan UU No. 18 Tahun 1997 sepertinya merupakan langkah dalam rangka merespon arah kebijakan Tax Reform yang dilakukan Pemerintah pada tahun 1983. Undangundang ini merupakan suatu bentuk reformasi format pajak serta retribusi yang dapat dipungut di daerah. UU No. 18 Tahun 1997 Jika dicermati ternyata mengamanatkan bahwa dalam hal ada tingkatan daerah atau daerah tertentu ingin membuat suatu jenis pajak daerah, maka pajak daerah yang baru tersebut harus diatur dalam suatu peraturan pemerintah.

Memasuki era reformasi pemerintahan pada tahun 1998 yang ditandai dengan tumbangnya Rezim Orde Baru, maka ketentuan tentang pajak daerah juga mengalami perubahan yaitu dengan diubahnya UU Nomor 18 Tahun 1997 menjadi UU Nomor 34 Tahun 2000. Peraturan perundangundangan ini menerapkan konsep desentralisasi

\footnotetext{
Nurmayani, “Implikasi Hukum Peralihan Kewenangan Pemungutan PBB P2 Dari Pemerintah Pusat Kepada Pemerintah Kabupaten/Kota (Studi di Kota Bandar Lampung)", Praevia Jurnal Ilmu Hukum, Vol. 6 No. 2, JuliDesember 2012, Lampung: FH Unila, hlm. 149
} 
fiskal dalam bidang perpajakan daerah. Kepada daerah (Pemerintahan Propinsi, Pemerintah Kabupaten/Kota), diberi keleluasaan untuk berkreasi dan memungut jenis pajak daerah baru sepanjang belum dipungut oleh tingkatan pemerintahan lainnya.

Kebijakan desentralisasi membawa konsekuensi daerah mempunyai kebebasan untuk mengatur dan mengurus sendiri dengan pengawasan dari Pemerintah Pusat atau satuan pemerintahan yang lebih tinggi tingkatannya dari daerah yang bersangkutan. Adanya pengawasan dari Pusat, maka kebebasan yang dimiliki oleh daerah tidak mengandung arti adanya kemerdekaan, apalagi jika dikaitkan bahwa Indonesia adalah negara hukum, maka segala kebijakan harus mendasarkan pada aturan hukum yang berlaku. ${ }^{4}$

Victor Imanuel berpendapat bahwa setiap negara yang menyatakan dirinya sebagai negara hukum, tidak dapat lepas dari peraturan perundangan, karena negara hukum menempatkan peraturan perundangan sebagai panduan dalam menyusun strutur kenegaraan dan menjalankannya dalam pemerintahan sehari-hari. Pemerintahan harus dijalankan dengan hukum, maka secara logis pemerintah tidak dapat melakukan tindakan yang menyimpang atau bahkan bertentangan dengan hukum. ${ }^{5}$

Penyerahan urusan-urusan tertentu kepada Daerah untuk diurus dan di atur atas dasar prakarsa dan kepentingan masyarakat daerah, tidak menjadikan daerah tersebut seperti negara dalam negara. Daerah tidak mempunyai kebebasan yang absolut, walaupun sistem otonomi yang diamanatkan oleh Pasal 18 ayat (8) UUD 1945 adalah otonomi yang seluas-luasnya, namun demikian Pemerintah Pusat masih tetap mempunyai peran dan fungsi untuk mengawasi jalannya penyelenggaraan pemerintahan daerah. ${ }^{6}$

Tahun 2009 pemerintah pusat melakukan amandemen peraturan perpajakan daerah yaitu dengan dikeluarkannya UU No. 28 Tahun 2009

Philipus, M. Hadjon, 1997, Pengantar Hukum Administrasi Indonesia, Yogyakarta: Gadjah Mada University Press, hlm. 79

5 Victor Emanuel, "Kewenangan Judikatif Dalam Pengujian Peraturan Kebijakan”, Jurnal Yudisial, Vol. 6, No. 1 Ap-ril 2013, Jakarta: Komisi Yudisial, hlm. 34 tentang Pajak Daerah dan Retribusi Daerah yang mencabut UU No. 34 Tahun 2000. Dalam UU Pajak daerah yang baru ini ternyata pemerintah pusat menerapkan kebijakan yang berbeda terhadap pajak sebagaimana tertuang di dalam $\mathrm{Pa}$ sal 2 ayat (2) tentang jenis pajak kabupaten/ kota dan ayat (3), yang mencantumkan secara tegas kepada kabupaten/kota untuk tidak memungut jenis pajak diluar yang sudah ditentukan di dalam ayat (2). Senada dengan materi pasal tersebut diatas tercantum di dalam Pasal 158 ayat (2) UU No. 32 Tahun 2004 tentang Pemerintahan Daerah yang menyebutkan bahwa Pemerintahan daerah dilarang melakukan pungutan atau dengan sebutan lain diluar yang telah ditetapkan UU.

Dominasi kebijakan tersebut tentunya secara teoritis menjadi sebuah bahan diskusi apalagi jika dikaitkan dengan makna otonomi daerah. Kebijakan pelaksanaan otonomi daerah dapat membawa harapan yang menjanjikan bagi keberhasilan mewujudkan pembangunan berkelanjutan. Dengan otonomi daerah, pemerintah daerah memiliki kewenangan untuk membuat sejumlah kebijakan yang sesuai dengan karakteristik wilayah dan aspirasi masyarakatnya. ${ }^{7}$

\section{Permasalahan}

Berdasarkan latar belakang pemikiran tersebut diatas, maka permasalaha yang dibahas pada artikel ini adalah sebagai berikut. Pertama, bagaimanakah Implementasi Kebijakan wewenang Pengelolaan Pajak Daerah dalam Kerangka Pelaksanaan Otonomi Daerah?; dan kedua, bagaimanakah Implementasi wewenang Pemerintah Pusat dan Pemerintah Daerah dalam pengelolaan pajak daerah ?

\section{Metode Penelitian}

Penelitian ini berfokus pada studi pustaka (library research), dengan mengutakan pengambilan data sekunder. Menurut Soerjono Soekanto dan Sri Mamudji, dalam penelitian hukum yang

\footnotetext{
Loc.cit

Slamet Rosyadi dan Anwaruddin,"Otonomi Daerah Dan Upaya Mewujudkan Paradigma Pembangunan Berkelanjutan”, Jurnal Sosial Ekonomi Humaniora, Vol. 2 No. 1 Mei-Oktober 2008, Purwokerto: Lembaga Penelitian Unsoed, hlm. 89
} 
dilakukan dengan cara meneliti bahan pustaka atau data sekunder maka disebut penelitian hukum normatif. 8

Untuk melengkapi data, maka dalam penelitian ini akan dilengkapi dengan data lapangan dengan melakukan wawancara. Penelitian hukum normatif, data pustaka saja tidak cukup sehingga harus dilengkapi dengan studi lapangan (fied research). Wawancara akan dilakukan di lo-kasi penelitian. Sejalan dengan karakter data tersebut maka data yang diperoleh selanjutnya dilakukan analisis secara kualitatif. Dalam hal bahan hukum dokumenter, khususnya yang diperoleh dari peraturan perundang-undangan, analisis dilakukan sesuai ajaran interpretasi yakni dengan metode hermeneutik.

Lokasi penelitian dilakukan di Kementerian Dalam Negeri dan di Direktorat Jenderal Pajak Jakarta, dan ditambah dengan 4 (empat) Kabupaten yaitu Kabupaten Bandung, Kabupaten Banyumas, Kabupaten Sleman dan Kabupaten Sidoarjo, sebagai 4 dari 26 kabupaten di Indonesia yang dijadikan sebagai kabupaten percontohan pelaksanaan otonomi daerah berdasarkan Peraturan Pemerintah No. 8 Tahun 1995 tentang Penyerahan Sebagian Urusan Pemerintahan Kepada 26 (Dua Puluh Enam) Daerah Tingkat II Percontohan.

\section{Pembahasan}

\section{Perkembangan Pengaturan Kebijakan Pajak} Daerah

Penarikan Pajak Daerah di Indonesia telah mulai diterapkan sejak jaman kolonial. Peraturan perundang-undangan yang mengatur Pemerintahan Daerah setelah Indonesia merdeka tertuang di dalam UU Nomor 22 Tahun 1948 tentang Peraturan tentang penetapan aturan-aturan pokok mengenai Pemerintahan sendiri di daerahdaerah yang berhak mengatur dan mengurus rumah tangganya sendiri. Dalam UU ini pungutan sudah secara jelas tercantum dalam Pasal 37 bahwa Pendapatan Daerah bersumber daripajak daerah, termasuk juga retribusi; hasil perusahaan daerah; pajak Negara yang diserahkan ke- pada daerahdan lain-lain sebagai salah satu sumber penerimaan asli daerah, pada masa ini belum ada peraturan perundangan yang secara spesifik mengatur pemungutan pajak daerah.

Sejarah pengaturan pajak daerah ditandai dengan beragamnya peraturan perundang-undangan yang ditetapkan oleh pemerintah pusat. Sejak masa kemerdekaan, peraturan perundangan yang mendasari pemungutan Pajak Daerah ada-lah sebagai berikut. Pertama, UU Darurat Nomor 11 Tahun 1957 tentang Peraturan Umum Pajak Daerah; kedua, UU Nomor 18 Tahun 1997 tentang Pajak Daerah dan Retribusi Daerah; ketiga, UU Nomor 34 Tahun 2000 tentang Perubahan atas UU Nomor 18 Tahun 1997 tentang Pajak Daerah dan Retribusi Daerah; dan keempat, UU Nomor 28 Tahun 2009 tentang Pajak Daerah dan Retribusi Daerah.

UU Darurat Nomor 11 Tahun 1957 tentang Peraturan Umum Pajak Daerah merupakan Undang-undang yang pertama dalam sejarah penyelenggaraan pemerintahan daerah di Indonesia. Pasal 14 menyebutkan Daerah Tingkat II (sekarang disebut Daerah Kabupaten/Kota), diberi wewenang memungut sejumlah jenis pajak daerah yaitu: Pajak atas pertunjukkan dan keramaian umum; Pajak atas reklame sepanjang tidak diadakan dengan memuatnya dalam majalah atau warta harian; Pajak anjing; Pajak atas izin penjualan atau pembikinan petasan dan kembang api; Pajak atas izin penjualan minuman yang mengandung alkohol; Pajak atas kendaraan tidak bemotor; Pajak atas izin mengadakan perjudian; Pajak atas tanda kemewahan mengenai luas dan penghiasan kubur; Pajak karena berdiam di suatu daerah lebih dari 120 hari dalam satu tahun pajak, kecuali untuk perawatan di dalam rumah sakit, dan juga atas penyediaan rumah lengkap dengan perabotnya untuk diri sendiri atau keluarganya selama lebih dari 120 hari dari suatu tahun pajak, semua itu tanpa bertinggal tetap di daerah itu, dengan ketentuan, bahwa mereka yang berdiam di luar daerahnya guna menjalankan tugas yang diberikan oleh negara atau daerah, tidak boleh dikenakan pajak di-

8 Soerjono Soekanto dan Sri Mamudji, 1994, Penelitian Hukum Normatif Suatu Tinjuan Singkat, Jakarta: Rajagrafindo Pers, hlm. 14 
maksud; Pajak atas milik berupa bangunan serta ha-lamannya yang berbatasan dengan jalan umum di darat atau di air, atau yang terletak di sekitar-nya, dan juga atas milik berupa tanah kosong yang berbatasan atau yang mempunyai jalan ke luar pada jalan-jalan tersebut; Pajak atas milik berupa bangunan serta keturutannya atau tanah kosong yang terletak dalam bagian tertentu dari daerah, pajak mana dipungut tiaptiap tahun untuk paling lama 30 tahun atas dasar sumbangan yang layak guna pembiayaan pekerjaan yang diselenggarakan oleh atau dengan bantuan daerah dan yang menguntungkan milikmilik tersebut; Pajak atas milik berupa bangunan serta hala-mannya yang berbatasan dengan jalan umum di darat atau di air atau dengan lapangan, atau pajak atas tanah yang menurut rencana bangunan daerah yang telah disahkan akan dipergunakan sebagai tanah bangunan dan terletak dalam lingkungan yang ditentukan oleh Dewan Perwakilan Rakyat Daerah; Pajak sekolah yang semata-mata diperuntukkan membiayai pembangunan rumah sekolah rendah untuk pelajaran umum dan pembelian perlengkapan pertama; dan Opsen atas pokok pajak daerah tingkat atasannya sepanjang memungkinkan pemungutan opsen itu diberikan dalam peraturan pajak daerah tingkat ini.

Pada tahun 1956 Pemerintah mengeluarkan UU No. 32 Tahun 1956 tentang Perimbangan Keuangan antara Negara dengan Daerah-daerah yang Berhak Mengurus Rumah Tangganya Sendiri yang selanjutnya disebut dengan UU Perimbangan Keuangan 1957. Dalam Pasal 3 ayat (1) Pajak Negara yang ada, tersebut di bawah ini, dinyatakan sebagai pajak-daerah: Pajak verponding (Ordonansiverponding 1928); pajak verponding Indonesia (Ordonansi verponding Indonesia); pajak rumah tangga (Ordonansi pajak rumah tangga 1908); pajak kendaraan bermotor (Ordonansi PKB 1934); pajak jalan (Ordonansi pajak jalan 1942); pajak potong (Ordonansi pajak potong 1936); pajak kopra (Undang-undang Indonesia

Deden Sumantry, "Reformasi Perpajakan sebagai Perlindungan Hukum yang Seimbang Antara Wajib Pajak dengan Fiscus Sebagai Pelaksanaan Terhadap Undang-undang Perpajakan”, Jurnal Legislasi Indonesia, Vol. 8 No. 1 April 2011, Jakarta: Kemenkumham RI, hlm. 13
Timur No. 16 tahun 1949"; dan pajak pembangunan (Undang-undang pajak pembangunan, Undang-undang Republik Indonesia No. 14 tahun 1947");

Pada tahun 1983 Pemerintah melakukan pembaharuan pajak (tax reform). Reformasi merupakan suatu hal yang penting. Menurut Deden Sumantry reformasi perpajakan sebagai perlindungan hukum yang seimbang antara wajib pajak dengan fiscus, namun kebijakan reformasi pajak yang dilakukan tidak menyentuh kebijakan pajak daerah, dengan demikian ketentuan tentang pajak daerah masih menggunakan aturan produk orde lama. ${ }^{9}$

Menurut Fuad Bawazier bahwa Pajak adalah sumber terpenting penerimaan negara dan oleh karena itu reformasi pajak harus dilaksanakan secara obyektif dengan target dan sasaran yang jelas. Reformasi pajak juga harus memperhatikan aspek keadilan, daya saing ekonomi, kemudahan dan kelancaran dalam pelaksanaan, serta dengan biaya yang efisien. ${ }^{10}$

Reformasi terhadap ketentuan pajak daerah baru dilakukan oleh Pemerintah pada tahun 1997. Pemerintah menerbitkan dan melaksanakan serangkaian UU perpajakan yang telah dilaksanakan pada tahun-tahun sebelumnya, dan untuk pajak daerah ditetapkan UU No. 18 tahun 1997 tentang Pajak dan Retribusi Daerah. Pemberlakuan UU ini dengan pertimbangan bahwa pajak daerah dan retribusi daerah merupakan sumber pendapatan daerah yang penting guna membiayai penyelenggaraan pemerintahan daerah dan pembangunan daerah untuk memantapkan otonomi daerah yang nyata, dinamis, serasi, dan bertanggung jawab dengan titik berat pada Daerah Tingkat II.

Pertimbangan lain diberlakukannya UU tahun 1997 termuat di dalam Penjelasan umum yaitu bahwa UU Nomor 11 Drt. Tahun 1957 tentang Peraturan Umum Pajak Daerah yang selama ini berlaku telah menyebabkan Daerah berpeluang untuk memungut banyak jenis pajak, beberapa

10 Fuad Bawazier, "Reformasi Pajak di Indonesia", Jurnal Legislasi Indonesia, Vol. 8 No. 1 April 2011, Jakarta: Kemenkumham RI, hlm. 2 
diantaranya mempunyai biaya administrasi yang lebih tinggi dibandingkan dengan hasilnya dan atau hasilnya tidak memadai. Terdapat beberapa jenis pajak yang tidak memadai untuk di pungut Daerah karena tumpang tindih dengan pajak lain dalam arti terdapat pajak lain untuk jenis objek yang sama, menghambat efisiensi alokasi sumber ekonomi, bersifat tidak adil, atau tidak benar-benar bersifat pajak, tetapi bersifat retribusi.

Pasal 2 ayat (2) UU Pajak daerah dan Retribusi daerah tahun 1997 menyebutkan bahwa Jenis Pajak Daerah Tingkat II terdiri dari; Pajak Hotel dan Restoran; Pajak Hiburan; Pajak Reklame; Pajak Penerangan Jalan; Pajak Pengambilan dan Pengolahan Bahan Galian Golongan C; Pajak Pemanfaatan Air Bawah Tanah dan Air Permukaan. UU masih membuka kemungkinan untuk diadakannya jenis pajak daerah baru hal itu termuat di dalam Pasal 3 mengamanatkan bahwa dengan Peraturan Pemerintah dapat ditetapkan jenis pajak selain yang ditetapkan pada ayat (1) dan ayat (2) yang memenuhi kriteria bersifat sebagai pajak dan bukan retribusi; objek dan dasar pengenaan pajak tidak bertentangan dengan kepentingan umum; potensinya memadai; tidak memberikan dampak ekonomi yang negatif; memperhatikan aspek keadilan dan kemampuan masyarakat; menjaga kelestarian lingkungan.

Ketentuan tersebut sepertinya membuka untuk adanya jenis pajak daerah baru, namun sejatinya jelas terlihat bahwa keharusan keberadaan peraturan pemerintah sebagai wadah bagi jenis pajak daerah baru yang akan diterapkan mengindikasikan adanya suatu upaya pemerintah pusat untuk mempersulit daerah untuk berkreasi memungut jenis pajak daerah yang baru. Tidaklah berlebihan apabila dikatakan bahwa UU Pajak daerah 1997 telah menutup kemungkinan bagi daerah untuk dengan inisiatif sendiri memberlakukan jenis pajak daerah baru.

Menurut Fuad Bawazier kebijakan perpajakan tahun 1997 telah kehilangan arah dan salah sasaran yang ingin dicapai dan bersifat asalasalan dan sekedar mengikuti trend politik dalam era reformasi. Banyak yang berpendapat bahwa perubahan yang terjadi lebih dilatarbelakangi oleh motif politik atau sekedar cara untuk memperpanjang jabatan. Salah satu contoh yaitu dengan adanya ambisi menambah jumlah NPWP dari di bawah 1 juta menjadi minimal 10 juta padahal penambahan NPWP tidak otomatis menambah WP. ${ }^{11}$

Kebijakan tersebut diatas tentunya tidak akan lepas dari kebijakan penyelenggaraan pemerintahan di daerahyang berlaku pada saat itu yaitu pada masa berlakunya UU NO. 5 Tahun 1974 tentang Pokok-Pokok Pemerintahan di Daerah. Penjelasan Umum UU No. 5 Tahun 1974 menyebutkan bahwa prinsip otonomi yang dipakai bukan lagi "Otonomi yang riil dan seluasluasnya" tetapi "Otonomi yang nyata dan bertanggungjawab". Istilah "seluas-luasnya" tidak lagi dipergunakan karena berdasarkan pengalaman selama ini istilah tersebut ternyata dapat menimbulkan kecenderungan pemikiran yang dapat membahayakan keutuhan Negara Kesatuan dan tidak serasi dengan maksud dan tujuan pemberian otonomi kepada Daerah. Hakekatnya Otonomi Daerah itu lebih merupakan kewajiban daripada hak,yaitu kewajiban Daerah untuk ikut melancarkan jalannya pembangunan sebagai sarana untuk mencapai kesejahteraan Rakyat yang harus diterima dan dilaksanakan dengan penuh tanggungjawab.

Kesimpulan yang dapat diambil dalam penyelenggaraan pemerintahan daerah pada masa ini adalah bahwa Pemerintah Daerah (Daerah Tingkat II) adalah merupakan kepanjangan tangan dari Pemerintah Pusat. Hal itu dapat terlihat dari bunyi Pasal 79 yang menegaskan bahwa Kepala Daerah Tingkat II karenajabatannya adalah Kepala Wilayah Kabupaten atau Kotamadya, kemudian dalam Pasal 80 bahwa Kepala Wilayah sebagai Wakil Pemerintah adalah Penguasa Tunggal dibidang pemerintahan dalam wilayahnya dalam arti memimpin pemerintahan mengkoordinasikan pembangunan dan membina kehidupan masyarakat di segala bidang.

Ketentuan Pasal tersebut sama dengan materi Pasal 44 UU No. 18 Tahun 1965 yang menyebutkan bahwa kedudukan Kepala daerah

11 Ibid, hlm. 16 
adalah sebagai alat Pemerintah Pusat. Sebagai alat Pemerintah Pusat Kepala Daerah memegang pimpinan kebijaksanaan politik di daerahnya, menyelenggarakan koordinasi antara jawatanjawatan Pemerintah Pusat di Daerah, melakukan pengawasan atas jalannya Pemerintah Daerah; dan menjalankan tugas-tugas lain yang diserahkan kepadanya oleh Pemerintah Pusat. Mendasarkan pada bunyi pasal tersebut praktis sebetulnya pada masa ini tidak ada otonomi daerah dalam arti yang sesungguhnya.

Krishna D. Durumurti berpendapat bahwa pada masa pemerintahan orde baru kekuasan politiknya menjadi totaliter pada diri suharto dan DPR dibawah pengaruh suharto. Daerah otonom yang ditentukan oleh DPR dalam UU bukanlah daerah yang otonom karena daerah tidak memiliki otonominya. ${ }^{12}$

Seiring dengan gerakan reformasi yang menentang pemerintahan Suharto, maka paradigma tentang penyelenggaraan pemerintahan daerah juga mengalami perubahan yang sangat mendasar. UU No. 5 tahun 1974 sebagai norma pelaksanaan otonomi daerah dicabut dan diganti dengan UU No. 22 Tahun 1999 tentang Pemerintahan Daerah.

Dikatakan terjadi perubahan paradigma dalam penyelenggaran pemerintahan di daerah dikarenakan semangat yang dibawa di dalam penyelenggaraan otonomi daerah adalah otonomi yang seluas-luasnya. Otonomi bukan lagi sekedar merupakan kewajiban pemerintah daerah sebagaimana digariskan di dalam UU No 5 Tahun 1974 namun merupakan hak untuk mengatur dan mengurus sendiri urusan pemerintahan dan kepentingan masyarakat.

Pasal 32 UU No 22 Tahun 1999 menegaskan bahwa dalam menjalankan tugas dan kewenangan selaku Kepala Daerah, Bupati/Walikota bertanggung jawab kepada DPRD Kabupaten/Kota. Norma pertanggung jawaban ini lah yang pada akhirnya memunculkan dominasi legislatif di daerah yang pada akhirnya memunculkan suasana yang kurang harmonis antara eksekutif dan legislatif.

12 Krishna D. Durumurti, "Hukum Pajak atau Hukum dan Pajak, Refleksi Hukum", Jurnal Ilmu, Edisi Oktober 2010, Salatiga:Fakultas Hukum UKSW, hlm. 148
Dominasi legislatif yang notabene adalah merupakan lembaga politik, maka jelas bahwa norma sebagai dasar pelaksanaan otonomi daerah banyak dipengaruhi oleh kepentingan politik. Menurut Edy Kastro, dalam hubungan tolak tarik antara politik dan hukum maka hukumlah yang terpengaruh oleh politik, karena sub sistem politik memiliki konsentrasi energi yang lebih besar daripada hukum. Karena lebih kuatnya konsentrasi energi dari politik maka menjadi beralasan adanya konstatasi bahwa kerapkali otonomi hukum di Indonesia dintervensi oleh politik, bukan hanya dalam proses pembuatannya tetapi juga dalam implementasinya. ${ }^{13}$

Dominasi legislatif yang terjadi sejalan dengan prinsip-prinsip pemberian Otonomi Daerah yang dijadikan pedoman dalam UU sebagaimana termuat di dalam Penjelasan Umum UU No. 22 tahun 1999 diantaranya adalah bahwa pelaksanaan Otonomi Daerah yang luas dan utuh diletakkan pada Daerah Kabupaten dan Daerah Kota, sedang Otonomi Daerah Propinsi merupakan oto-nomi yang terbatas dan pelaksanaan Otonomi Daerah harus lebih meningkatkan peranan dan fungsi badan legislatif Daerah, baik sebagai fungsi legislasi, fungsi pengawas maupun fungsi anggaran atas penyelenggaraan Pemerintahan Daerah.

Pengaturan di bidang keuangan daerah $\mathrm{Pa}-$ sal 79 UU 22/1999 memuat ketentuan bahwa pajak daerah adalah salah satu sumber PAD. Ketentuan Pasal 82 menegaskan bahwa Pajak dan retribusi daerah ditetapkan dengan UU, penentuan tarif dan tata cara pemungutan pajak dan retribusi daerah ditetapkan dengan Peraturan Daerah sesuai dengan peraturan perUUan. Berbeda dengan UU 5/1974 yang memberikan ketentuan tambahan di dalam Pasal 58 yang secara garis besar menegaskan bahwa Perda pajak daerah berlaku sesudah ada pengesahan pejabat yang berwenang, maka di dalam ketentuan UU 22 tahun 1999 batasan seperti itu tidak ditemukan. Ketentuan Pasal 82 menegaskan bahwa Pajak dan retribusi Daerah ditetapkan dengan UU dan penentuan tarif dan tata cara pemungutan

13 Edy Kastro, "Hubungan Kausalitas Antara Politik dan Hukum”, Jurnal Hukum, Vol. VII. No. 1, Edisi Januari 2009, Palembang: PPS Universitas Sriwijaya, hlm. 34 
pajak dan retribusi daerah ditetapkan dengan Peraturan Daerah sesuai dengan peraturan perundangan. Bunyi pasal tersebut terkesan bahwa secara normatif ada keleluasaan bagi daerah untuk melakukan pemungutan pajak daerah.

Pemerintah mengeluarkan UU No. 34 Tahun 2000 Tentang Perubahan Atas UU Republik Indonesia Nomor 18 Tahun 1997 Tentang Pajak Daerah Dan Retribusi Daerah. Perubahan kebijakan yang mendasar tercantum di dalam Pasal 2 ayat (2) yang menyebutkan bahwa dengan Peraturan Daerah dapat ditetapkan jenis pajak Kabupaten/Kota selain yang ditetapkan dalam ayat (2). Perubahan mendasar dapat diketahui dengan adanya amanat untuk adanya jenis perda baru pada masa UU 18 Tahun 1997 harus dalam bentuk Peraturan Pemerintah, namun dalam perubahannya perda baru dapat dikeluarkan cukup dengan perda. Kebijakan perpajakan daerah pada tahun 2000 ini dapat dikatakan searah dan sejalan dengan arah kebijakan penyelenggaraan pemerintahan di bidang keuangan daerah sebagaimana tertuang dalam UU No. 22 Tahun 1999.

Kehadiran UU No. 34 Tahun 2000 telah menimbulkan angin segar bagi daerah dan memunculkan harapan untuk adanya kesempatan bagi daerah menggali sumber pendapatan secara optimal. Namun dalam kenyataannya keleluasaan otonomi dalam penyelenggaran pemerintahan daerah yang digariskan dalam UU 22 Tahun 1999 dan keleuasaan menggali sumber pajak daerah sebagaimana diamanatkan dalam Undang-undang pajak daerah 34 Tahun 2000 telah memunculkan efek yang tidak diharapkan.

Saat ini yang terjadi adalah adanya euforia otonomi, namun euforia itu tidak dibarengi de-ngan dibangunnya etos kerja dan peningkatan kualitas sumber daya manusia. Pengambil kebijakan yang sebelumnya berada dalam suasana dan pola pikir yang sentralistik dalam suasa seperti ini menjabaran pelaksanaan otonomi cenderung diartikan menurut kepentingannya sendiri.

14 Fatkhurohman, "Implikasi Pembanlan Perda Terhadap Ketepatan Proporsi Teori Penegakan Hukum Dalam Sistem Peradilan di Indonesia", Jumal Dinamika Hukum, Vol.13 No. 1 Januari 2013, Purwokerto: Fakultas Hukum Unsoed, hlm.17
Kebebasan daerah untuk menggali potensi pendapatan daerah melalui pajak daerah dalam banyak hal telah menimbulkan permasalahan di antranya adalah adanya pemungutan ganda, ekonomi buaya tingga dan disinvestasi di daerah. Tim Investasi, Direktorat Perencanaan Makro, Kementerian Perencanaan Pembangunan Nasional (Bappenas), pada bulan Agustus 2005 mem-berikan informasi tentang perda bermasalah sebagaimana tampak pada tabel di bawah ini.

Tabel 1. Perda Bermasalah di Indonesia

\begin{tabular}{|c|l|c|c|}
\hline No & Jenis Peraturan Daerah & Jumlah & Persentase \\
\hline 1 & Pajak Daerah & 652 & 19,2 \\
\hline 2 & Retribusi Daerah & 2573 & 75,8 \\
\hline 3 & Sumbangan Pihak Ketiga & 21 & 0,6 \\
\hline 4 & Badan Usaha Milik Daerah & 25 & 0,7 \\
\hline 5 & PAD lain-lain & 7 & 0,2 \\
\hline 6 & Pencabutan Perda & 15 & 0,4 \\
\hline 7 & Lain-lain & 100 & 3,0 \\
\hline Jumlah Perda Diterima & 3393 & 100,0 \\
\hline $\begin{array}{l}\text { Jumlah Perda yang } \\
\text { Direkomendasikan Menkeu } \\
\text { kepada Mendagri untuk } \\
\text { Dibatalkan }\end{array}$ & 293 & 8,6 \\
\hline $\begin{array}{l}\text { Jumlah Perda yang Dibatalkan } \\
\text { Mendagri atas dasar } \\
\text { rekomendasi Menkeu,dan } \\
\text { lainnya }\end{array}$ & 255 & 7,5 \\
\hline $\begin{array}{l}\text { Sumber: Direktorat Pendapatan Daerah, Juni } 2004 \\
\end{array}$ & & \\
\hline
\end{tabular}

Pengujian peraturan daerah adalah menjadi kewenangan Pusat namun demikian hendaknya kewenangan tersebut tidak menjadi jalan bagi Pusat untuk superioritas kekuasaan atas Pemerintah Daerah dan hukum-hukum lokal yang di agregasi kedalam Peraturan daerah. ${ }^{14}$ Pembatalan Perda dan Peraturan Kepala Daerah mau pun bentuk yang lain merupakan keniscayaan da-lam mewujudkan peran dan fungsi hukum dalam menopang proses pembangunan. ${ }^{15}$

Melalui serangkaian kontroversi, maka dilakukan revisi terhadap UU No.22 tahun 1999

15 Jazim Hamidi, “Paradigma Baru Pembentukan dan Analisis Peraturan Daerah (Studi Atas Perda Peloyanan Publik dan Perda Keterbukaan Informasi Publik)", Jurnal Hukum, Vol. 18, No. 3, Juli 2011, Malang: Fakultas Hukum Unibraw, hlm. 336 
tentang Pemerintahan Daerah, dengan ditetapkannya UU No. 32 Tahun 2004 tentang Pemerintahan Daerah sebagaimana telah diubah beberapa kali terakhir dengan UU No. 12 Tahun 2008, namun UU No. 32 tahun 2004 tentang Pemerintahan Daerah sebagai penggantinya ternyata masih juga menuai pro-kontra.

Daerah dalam penyelenggaraan otonomi, mempunyai beberapa hak dan salah satunya adalah hak untuk memungut pajak daerah dan retribusi daerah (Pasal 21.e), pajak daerah adalah salah satu sumber pendapatan asli daerah (Pasal 157.a), namun begitu, meski daerah berhak memungut pajak daerah di dalam Pasal 158 terdapat suatu ketentuan bahwa pemerintahan daerah dilarang melakukan pungutan atau dengan sebutan lain diluar yang telah ditetapkan Undang-undang. Ketentuan tentang pajak daerah diatur lebih lanjut di dalam pasal 185 bahwa rancangan Perda pajak daerah yang telah disetujui bersama sebelum ditetapkan oleh Gubernur paling lambat 3 (tiga) hari disampaikan kepada Menteri Dalam Negeri untuk dievaluasi. Selain itu menurut ketentuan Pasal 189 proses penetapan rancangan Perda yang berkaitan dengan pajak daerah, harus dikoordinasikan terlebih dahulu dengan Menteri Keuangan.

Ketentuan tersebut di atas, menunjukan bahwa UU No. 32 Tahun 2004 berupaya mengeliminir permasalahan yang terjadi terkait dengan banyaknya pungutan di daerah sebagai akibat adanya keleluasaan daerah dalam memungut pajak daerah. Dengan diberlakukannya UU No. 32 Tahun 2004 meski secara normatif tidak menghapus wewenang daerah untuk memungut pajak sebagaimana digariskan di dalam UU No. 34 Tahun 2000, akan tetapi dengan diberlakukannya ketentuan tentang mekanisme evaluasi terhadap peraturan daerah, maka semua perda yang berkaitan dengan pungutan harus mengikuti aturan yang telah digariskan dalam UU $32 \mathrm{Ta}$ hun 2004. Pemberlakuan UU No. 32 Tahun 2004 disamping dapat meredam disharmoni yang terjadi antara eksekutif dan legislatif juga telah menyambung lagi jalur koordinasi antara Pemerintah Propinsi dan Pemerintah Kabupaten/Kota. Selain itu amanat yang dicantumkan terkait dengan mekanisme pemberlakuan pungutan da- erah dapat mengeliminir terjadinya ekonomi biaya tinggi akibat banyaknya pungutan yang dilakukan di daerah.

Diberlakukannya UU Nomor 32 Tahun 2004 tentang Pemerintahan Daerah sebagaimana telah diubah beberapa kali terakhir dengan UU Nomor 12 Tahun 2008 tentang Perubahan Kedua atas UU Nomor 32 Tahun 2004 tentang Pemerintahan Daerah, sebagaimana telah diuraikan di muka dapat diketahui bahwa penyelenggaraan pemerintahan daerah dilakukan dengan memberikan kewenangan yang seluas-luasnya, disertai dengan pemberian hak dan kewajiban menyelenggarakan otonomi daerah dalam kesatuan sistem penyelenggaraan pemerintahan negara.

Tanggal 18 Agustus 2009, Dewan Perwakilan Rakyat Republik Indonesia telah menyetujui dan mengesahkan Rancangan UU Pajak Daerah dan Retribusi Daerah (RUU PDRD) menjadi UU, sebagai pengganti UU Nomor 34 Tahun 2000. Perubahan tersebut dilakukan untuk menyesuaikan dengan arah kebijakan tentang pemungutan pajak daerah juga mengalami perubahan.

Beberapa pertimbangan ditetapkannya UU 28 Tahun 2009 adalah bahwa dalam rangka meningkatkan pelayanan kepada masyarakat dan kemandirian daerah, perlu dilakukan perluasan objek pajak daerah dan retribusi daerah dan pemberian diskresi dalam penetapan tarif, selain itu UU Nomor 18 Tahun 1997 tentang Pajak Daerah dan Retribusi Daerah sebagaimana telah diubah dengan UU Nomor 34 Tahun 2000 tentang Perubahan atas UU Nomor 18 Tahun 1997 tentang Pajak Daerah dan Retribusi Daerah, perlu disesuaikan dengan kebijakan otonomi daerah.

Pemberlakuan Undang-undang PDRD bertujuan memberikan kewenangan yang lebih besar kepada daerah dalam perpajakan dan retribusi, meningkatkan akuntabilitas daerah dalam penyediaan layanan dan penyelenggaraan pemerintahan. Jangkauan lain yang akan dicapai adalah dalam rangka memperkuat otonomi daerah, memberikan kepastian bagi dunia usaha mengenai jenis-jenis pungutan daerah.

Penjelasan Umum Undang-undang PDRD menyebutkan bahwa pengaturan kewenangan perpajakan dan retribusi yang ada saat ini kurang mendukung pelaksanaan otonomi Daerah. 
Pemberian kewenangan yang semakin besar kepada Daerah dalam penyelenggaraan pemerintahan dan pelayanan kepada masyarakat seharusnya diikuti dengan pemberian kewenangan yang besar pula dalam perpajakan dan retribusi. Basis pajak kabupaten dan kota yang sangat terbatas dan tidak adanya kewenangan dalam penetapan tarif pajak mengakibatkan Daerah selalu mengalami kesulitan untuk memenuhi kebutuhan pengeluarannya.

Kebijakan baru yang tertuang di dalam UU PDRD Tahun 2009 yaitu adanya penambahan 4 jenis pajak daerah yaitu 1 jenis pajak provinsi dan 3 jenis pajak kabupaten/kota. Secara keseluruhan dengan adanya penambahan tersebut maka terdapat 16 jenis pajak daerah, yaitu 5 jenis pajak provinsi dan 11 jenis pajak kabupaten/kota. Jenis pajak provinsi yang baru adalah Pajak Rokok, sedangkan 3 jenis pajak kabupaten/kota yang baru adalah PBB Perdesaan dan Perkotaan, BPHTB, dan Pajak Sarang Burung Walet. Untuk kabupaten/kota ada penambahan 1 jenis pajak yaitu Pajak Air Tanah yang sebelumnya merupakan pajak provinsi.

UU No. 28 Tahun 2009 di dalamnya mengandung materi muatan yang sifatnya korektif terhadap Undang-undang pajak daerah sebelumnya. Jika UU No. 18 Tahun 1997 dan UU no. 32 Tahun 2000 memberi keluasaan untuk adanya jenis pajak daerah baru, maka UU no. 28 Tahun 2009 secara tegas telah menutup peluang tersebut. Dalam UU pajak daerah lama, tidak ada ketegasan sanksi bagi daerah yang berspekulasi tetap menerapkan pajak daerah meski perda telah dibatalkan, maka di dalam UU No. 28 Tahun 2009 terhadap pelanggaran ketentuan Undang-undang pajak, maka akan terkena sanksi. Penjelasan Umum Undang-undang menyebutkan sanksi berupa penundaan dan/ataupemotongan dana alokasi umum dan/atau dana bagi hasil atau restitusi.

Permasalahan yang muncul di daerah dengan pembelakuan UU no. 28 Tahun 2009 adalah yang terkait dengan "pendaerahan" PBB P2 dan BPHTB. Meski kedua jenis pajak tersebut di dae-

16 Banu Witono, "Peranan Pengetahuan Pajak Pada Kepatuhan Wajib Pajak", Jurnal Akuntansi dan Keuangan, Vol. rahkan dengan masa peralihan yang cukup, namun didalam implementasinya banyak menemui kendala dan kendala utama yang dihadapi oleh daerah (kabupaten/kota) adalah yang berkenaan dengan perbedaan tatacara penghitungan PBB P2.

Mekanisme penghitungan PBB yang terdapat di dalam Pasal 6 (UU Nomor 12 Tahun 1994 tentang PBB) berbeda dengan mekanisme yang terdapat di dalam pasal 79, 80 dan 81 UU No. 28 Tahun 2009 dan jika dibandingkan maka hasil akhir penghitungan akan menunjukan bahwa jumlah PBB yang harus dibayar jika menggunakan norma UU 28 Tahun 2009 cenderung lebih besar. Hal ini yang memunculkan keengganan wajib pajak daerah untuk membayar pajak.

Kebijakan perpajakan yang baik pada dasarnya akan berpengaruh terhadap kepatuhan wajib pajak. Dalam satu sistem yang menekankan keaktifan wajib pajak, maka kepatuhan perpajakan sangat diperlukan. Kepatuhan pajak (Tax compliance) dalam kaitannya dengan Wajib Pajak, dapat didefinisikan sebagai perilaku Wajib Pajak dalam memenuhi kewajiban perpajakannya sesuai dengan peraturan yang berlaku. Perilaku tersebut sangat dipengaruhi oleh motivasi. Menurut Budiatmanto, biasanya motivasi akan berpengaruh terhadap intensitas perilaku (termotivasi, tanpa motivasi, dan apatis), dan kesesuaian dengan tujuan perilaku (efektif, tidak efektif). ${ }^{16}$

\section{Implementasi Wewenang Pengelolaan Pajak Daerah}

Sebagai daerah otonom, maka setiap kabupaten mempunyai kewenangan untuk mengurus rumah tangganya sendiri. Merujuk pada ketentuan UUD Negara Republik Indonesia Tahun 1945 Pasal 18 ayat (2) bahwa Pemerintahan daerah propinsi, daerah kabupaten, dan kota mengatur dan mengurus sendiri urusan pemerintahan menurut asas otonomi dan tugas pembantuan.

Meski sebagai daerah yang sudah dinyatakan sebagai daerah otonom namun di dalam pelaksanaannya tetap mengacu pada ketentuan

7, No.2, September 2008, Surabaya: Fakultas Ekonomi Universitas Muhammadiyah, hlm. 196-208. 
yang digariskan oleh Pemerintah Pusat. Penyusunan instrumen penyelenggara pemerintahan daerah diatur dalam UU No. 32 tahun 2004 yang dilaksanakan lebih lanjut dengan PP No. 41 Tahun 2007 tentang Organisasi Perangkat daerah. Menurut ketentuan PP No. 41 tahun 2007, yang dimaksud dengan Perangkat daerah kabupaten adalah unsur pembantu kepala daerah dalam penyelenggaraan pemerintahan daerah yang terdiri dari sekretariat daerah, sekretariat DP$\mathrm{RD}$, dinas daerah, lembaga teknis daerah, kecamatan, dan kelurahan.

Ketentuan Pasal 11 ayat (3) UU No. 32 Tahun 2004 mengamanatkan bahwa dalam penyelenggaraan pemerintahan daerah, maka daerah memiliki urusan yang terdiri dari urusan wajib dan urusan pilihan. Ketentuan Pasal 14 ayat (2) menyebutkan bahwa urusan pemerintahan kabupaten/kota yang bersifat pilihan meliputi urusan pemerintahan yang secara nyata ada dan berpotensi untuk meningkatkan kesejahteraan masyarakat sesuai dengan kondisi, kekhasan, dan potensi unggulan daerah yang bersangkutan.

Sebagai tindak lanjut dari ketentuan UU No 32 tahun 2004 tersebut maka Pemerintah mengeluarkan peraturan pelaksana dalam bentuk PP yaitu PP No. 38 Tahun 2007 tentang Pembagian Urusan Pemerintahan Antara Pemerintah Pusat dan Pemerintah daerah. Mengingat bahwa PP No. 38 Tahun 2008 adalah sebagai pelaksana dari Undang-undang maka materi muatan PP hanya bersifat penjabaran dari Undang-undang khususnya Pasal 14.

Urusan pilihan adalah urusan pemerintahan yang secara nyata ada dan berpotensi untuk meningkatkan kesejahteraan masyarakat sesuai dengan kondisi, kekhasan,dan potensi unggulan daerah yang bersangkutan yang meliputi: urusan kelautan dan perikanan; pertanian; kehutanan; energi dan sumber daya mineral; pariwisata; industri; perdagangan; dan ketransmigrasian.

Prinsip dasar dalam penyelenggaraan pemerintahan, bahwa pemerintah daerah wajib memperhatikan ketiga peraturan perundangan sebagaimana tersebut di atas, disamping peraturan perundangan yang lain. Jika dicermati maka urusan yang terkait dengan pajak daerah tidak diatur secara khusus di dalam ketiga pera- turan perundangan tersebut. Ketentuan yang termuat di dalam UU No. 32 Tahun 2004 tentang Pemerintahan Daerah pajak daerah hanya disebutkan sebagai salah satu sumber PAD. Jika dicermati maka di dalam PP No. 41 Tahun 2007 pajak daerah juga tidak jelas masuk dalam lingkup kewenangan lembaga yang mana dan di dalam PP No. 38 Tahun 2007 urusan pajak daerah tidak jelas masuk dalam urusan tingkatan yang mana. Jika dicermati lebih mendalam maka mestinya urusan pajak daerah merupakan urusan wajib Pemerintah daerah sebagai konsekuensi dari urusan otonomi daerah.

Urusan pajak daerah meskipun menjadi urusan daerah, namun semua peraturan perundangan pemerintahan daerah dan pajak derah yang pernah ada selalu mengamanatkan bahwa pengaturan pajak daerah wajib mendapat pengesahan dari Pemerintah Pusat, dan sebelum diberlakukan wajib melalui proses evaluasi dari Pusat atau pemerintahan yang lebih tinggi, selain itu mekanisme pengawasannya menggunakan pengawasan preventif dan represif.

Akibat dari mekanisme pengawasan preventif dan represif tersebut, maka campur tangan pemerintah pusat dalam penyusunan dan implementasi peraturan derah tentang pajak daerah menjadi tidak dapat dihindari. Untuk campur tangan pemerintah di dalam proses penyusunan perda sudah jelas termuat di dalam peraturan perundangan, sedangkan campur tangan Pemerintah Pusat yang terkait dengan pelaksaan perda pajak daerah adalah sebagai berikut. Pertama, Keputusan Menteri Dalam Negeri Nomor 43 Tahun 1999 Tentang Sistem dan Prose-dur Administrasi Pajak Daerah, Retribusi Daerah Dan Penerimaan Pendapatan Lain-Lain; kedua, Peraturan Menteri Dalam Negeri No. 53 Tahun 2007 Tentang Pengawasan Peraturan Daerah dan Peraturan Kepala Daerah; ketiga, Keputusan Menteri Dalam Negeri No. 41 Tahun 2001 Tentang Pengawasan Represif Kebijakan Daerah; keempat, Keputusan Menteri Dalam Negeri Nomor 27 Tahun 2002 Tentang Pedoman Alokasi Biaya Pemungutan Pajak Daerah; kelima, Keputusan Menteri Dalam Negeri Nomor 36 Tahun 2002 Tentang Alokasi Biaya Pemungutan Pajak Daerah Bagi Tim Pembina Pusat; dan keenam, Peraturan 
Menteri Dalam Negeri Nomor 56 Tahun 2010 Tentang Perubahan Atas Peraturan Menteri Dalam Negeri Nomor 57 Tahun 2007 Tentang Petunjuk Teknis Penataan Organisasi Perangkat Daerah

Ada penambahan fungsi pada Satuan Kerja Perangkat Daerah Kabupaten/Kota yang menangani fungsi pendapatan, pengelolaan keuangan dan aset daerah sebagaimana disebutkan dalam lampiran Permendagri, yaitu: pertama, Penyusunan kebijakan pelaksanaan pemungutan Bea Perolehan Hak Atas Tanah dan Bangunan (BPHTB) dan PBB perkotaan/pedesaan; kedua, pendataan, penilaian dan penetapan PBB perkotaan/pedesaan; ketiga, pengolahan data dan informasi Bea Perolehan Hak Atas Tanah dan Bangunan (BPHTB) dan PBB perkotaan/pedesaan; keempat, pelayanan Bea Perolehan Hak Atas Tanah dan Bangunan (BPHTB) dan PBB perkotaan/pedesaan; kelima, penagihan Bea Perolehan Hak Atas Tanah dan Bangunan (BPHTB) dan PBB perkotaan/pedesaan; dan keenam, pengawasan dan penyelesaian sengketa pemungutan Bea Perolehan Hak Atas Tanah dan Bangunan (BPHTB) dan PBB perkotaan/pedesaan; dan pelaporan dan pertanggungjawaban pelaksana-an tugas dan fungsi.

Data tersebut diatas menunjukan bahwa dalam rangka pelaksanaan perda tentang pajak daerah ternyata Pemerintah Pusat masih melakukan campur tangan dalam penentuan kebijakan pengelolaan pajak daerah. Mengacu pada ketentuan UU No. 32 Tahun 2004, dimana di dalam ketentuan umumnya menyebutkan bahwa Otonomi daerah adalah hak, wewenang, dan kewajiban daerah otonom untuk mengatur dan mengurus sendiri urusan pemerintahan dan kepentingan masyarakat setempat sesuai dengan peraturan perundang-undangan. ${ }^{17}$ Mendasarkan pada norma tersebut, maka Pemerintah Daerah tidak mempunyai kewenangan untuk menolak apalagi tidak menjalankan amanat yang telah digariskan semua demi keutuhan negara kesatuan Republik Indonesia.

Menyikapi kebijakan yang telah digariskan oleh Pemerintah Pusat baik dalam bentuk undang-undang atau peraturan pemerintah mau pun peraturan menteri atau keputusan setingkat menteri yang terkait dengan wewenang pengelolaan pajak daerah, maka daerah hanya melakukan pensikapan berupa penyesuaian kebijakan. Memasuki masa pembaharuan pajak daerah tahun 1997 yang ditandai dengan diundangkannya UU No. 18 tahun 1997, maka daerah juga ikut menyesuaikan dengan melakukan perubahan/ penggantian perda pajak daerah. Jenis pajak daerah yang sebelumnya bermacam-macam dan masih menggunakan produk hindia belanda sebagai bahan acuan, maka diganti dengan mengacu pada pada produk hukum nasional dan jenis pajak daerah yang diterapkan adalah Pajak Hotel dan Restoran; Pajak Hiburan; Pajak Reklame; Pajak Penerangan Jalan; Pajak Pengambilan dan Pengolahan Bahan Galian Golongan C; dan Pajak Pemanfaatan Air Bawah Tanah dan Air Permukaan.

Keadaan tidak berbeda dengan, dengan berlakunya UU No 34 tahun 2000 maka daerah juga cenderung mengikuti arahan dari Pusat. Informasi di lokasi penelitian menunjukan tidak ada satupun kabupaten yang menerapkan jenis perda pajak daerah diluar yang ditentukan dalam Pasal 2 ayat (2) yang menentukan adanya 7 (tujuh) jenis pajak kabupaten yang dapat dipungut, meski ayat (3) membuka kemungkina bagi daerah untuk meungut jenis pajak daerah yang lain.

Pensikapan oleh daerah terhadap kebijakan Pusat menjadi berbeda ketika Pusat dengan UU No. 28 Tahun 2009 mengeluarkan kebijakan yang mengalihkan pengelolaan PBB P2 dan BPHTB kepada daerah. Permasalahan yang muncul di daerah dengan pembelakuan UU No.28 Tahun 2009 adalah yang terkait dengan "pendaerahan" PBB P2 dan BPHTB. Kedua jenis pajak tersebut di daerahkan dengan masa peralihan yang cukup, namun didalam implementasinya banyak menemui kendala dan kendala utama yang dihadapi oleh daerah (kabupaten/kota) adalah yang berkenaan dengan perbedaan tatacara penghitungan PBB P2.

Mekanisme menghitungan PBB yang terdapat di dalam Pasal 6 (UU Nomor 12 Tahun 1994

17 Pasal 1 No. 32 Tahun 2004 
tentang $\mathrm{PBB}$ ) berbeda dengan mekanisme yang terdapat di dalam pasal 79, 80 dan 81 UU No. 28 Tahun 2009 dan jika dibandingkan maka hasil akhir penghitungan akan menunjukan bahwa jumlah PBB yang harus dibayar cenderung lebih besar. Hal ini yang memunculkan keengganan wajib pajak daerah untuk membayar pajak.

Daerah yang akan menerima pelimpahan pemungutan harus sudah melakukan langkah pensikapan. Langkah pensikapan yang penting yang harus dilakukan adalah yang terkait dengan penyiapan sumber daya manusia pelaksana, kelembagaan, teknologi, instrumen yuridis (Perda) serta sarana dan prasarana pendukung lainnya. ${ }^{18}$

Kebijakan pengalihan PBB dan BPHTB ini di beberapa daerah telah dilakukan beberapa persiapan baik melalui pembekalan SDM, penyesuaian produk hukum daerah (merevisi) maupun penataan kelembagaan daerah, di antaranya adalah sebagai berikut. Pertama, di Kabupaten Banyumas dengan mendasarkan pada Peraturan Daerah Kabupaten Banyumas No. 10 Tahun 2011 Tentang Perubahan Atas Peraturan Daerah No. 26 Tahun 2009 Tentang Organisasi Dan Tata Kerja Dinas Daerah dilakukan pemecahan bidang pendapatan menjadi 2 (dua) bidang yaitu bidang pendaftaran, pendataan dan penetapan yang menangani pendaftaran wajib pajak baru dan bidang pelayanan dan penagihan. Kedua, di Kabupaten Sleman dilakukan dengan memecah DPPKAD dengan Dipenda. Sebelumnya fungsi Dipen-da menjadi satu dengan DPPKAD, maka mulai tahun 2012 berdasarkan Peraturan Daerah Kabu-paten Sleman No. 12 Tahun 2011 Tentang Peru-bahan Atas Peraturan Daerah Kabupaten Sleman Nomor 9 Tahun 2009 Tentang Organisasi Perang-kat Daerah Pemerintah Kabupaten Sleman.

Ketiga, di Kabupaten Sidoarjo penanganan masalah pajak daerah dilakukan oleh Dinas Pendapatan Pengelolaan Kekayaan dan Aset (DPPKA). Dalam menghadapi pelimpahan PBB P2 dan BPHTB pemda melakukan pemberdayaan UPT yang ada di beberapa wilayah, selain itu DPPKA melakukan Oprasi Sisir yaitu gerakan jemput bo-

18 Kadar Pamuji, “Implikasi Kebijakan Pendaerahan Pengelolaan PBB Setelah Berlakunya UU No. 28 Tahun 2009 Tentang PDRD”, Jurnal Dinamika Hukum, Vol. 11, No. 1, la dalam rangka mengoptimalkan penerimaan PBB. Keempat, di Kabupaten Bandung penangan pajak daerah dilakukan oleh Dinas Pendapatan dan Pengelolaan Kekayaan. Terkait dengan kebijakan pendaerahan PBB maka Pemerintah Kabupaten Bandung dengan mendasarkan pada Perda No. 23 Tahun 2012 tentang Perubahan Ketiga Atas Peraturan Daerah Kabupaten Bandung Nomor 20 Tahun 2007 Tentang Pembentukan Organisasi Dinas Daerah Kabupaten Bandung membentuk UPTD

Kebijakan pendaerahan PBB P2 dan BPHTB ternyata sangat membantu meningkatkan PAD. Hal ini wajar mengingat potensi yang diperoleh dari PBB dab BPHTB adslah sangat besar. Sebelum adanya kebijakan tersebut, uang yang masuk ke kas daerah sebagai bagi hasil pajak sekitar $64 \%$ maka setelah didaerahkan seluruh pendapatan menjadi pemasukan daerah.

Mendasarkan pada uraian tersebut diatas maka dapat diketahui bahwa wewenang pengelolaan pajak daerah yang dimiliki oleh pemerintah daerah berasal dari pelimpahan wewenang yang dimiliki oleh pusat. Amanat yang tertuang di dalam Undang-undang pajak daerah yang berlaku menjadi kewajiban bagi daerah untuk melaksanakan secara bulat, namun demikian secara tegas di dalam Undang-undang diamanatkan bahwa daerah mempunyai wewenang untuk membuat perda tentang pajak daerah, namun ketika daerah akan mengimplentasikan wewenang yang udah secara tegas diberikan oleh UU tetap saja daerah mempunyai kewajiban untuk memperoleh pengesahan terlebih dahulu dari Pemerintah Pusat.

Kebijakan seperti tersebut di atas yang berlangsung secara terus menerus, memunculkan keengganan bagi daerah untuk menggali potensi pajak daerah diluar yang sudah ditentukan meski kemungkinan untuk menggali pajak daerah diluar yang sudah ditentukan dalam Undangundang pernah dilakukan (Pasal 2 ayat (3) UU No. 34 Tahun 2000). Di lain pihak apabila dicermati pengaturan tentang pajak daerah di dalam Undang-undang tentang Pemerintahan daerah,

Januari 2011, Purwokerto: Fakultas Hukum Unsoed, hlm. 125 
maka semakin erlihat bahwa ada keengganan dari pemerintah untuk melepas wewenang pengelolaan pajak daerah kepada pemerintah daerah.

Kewajiban adanya evaluasi bagi perda pajak daerah oleh pemerintah pusat sampai tongan dikeluarkannya Peraturan/Keputusan I teri Dalam Negeri yang mengatur tentang $p$ awasan perda maupun pembentukan Tim terkait dengan mekanisme pemungutan $\mathrm{p}$ daerah menunjukan bahwa Pemerintah $\mathrm{F}$ enggan untuk menyerahkan sepenuhnya pe lolaan pajak daerah kepada daerah.

Ketentuan undang-undang pemeri daerah menegaskan bahwa pajak daerah ad salah satu sumber PAD yang akan digunakar tuk penyelenggaraan pemerintahan daerah lam rangka pelaksanaan otonomi daerah,na sekali lagi jika kebijakan pemerintah pusat $\mathrm{t}$ seperti yang tercantum di dalam Undang-undang Pemerintahan daerah, maka pajak daerah tidak akan dapat diandalkan untuk digunakan sebagai penopang ekonomi daerah dalam rangka otonomi daerah.

Keengganan pusat untuk memperluas wewenang pengelolaan pajak daerah kepada daerah semakin terlihat dengan dikeluarkannya UU No. 28 Tahun 2009. Didaerahkannya PBB dan BPHTB adalah dalam rangka pemberdayaan daerah namun kebijakan clossed list yang diterapkan disertai dengan ancaman mengindikasikan bahwa daerah betul-betul dokondisikan untuk mengikuti arahan pusat di dalam pengelolaan pajak daerah. Alur pemikiran Kebijakan Pengelolaan Pajak daerah dalam rangka otonomi daerah sebagaimana diuraikan tersebut di atas apabila dibuat dalam bagan alir dapat dilihat pada bagan 1.

\section{Penutup \\ Simpulan}

Ada beberapa simpulan berdasar pada pembahasan permasalahan di atas. Pertama, Pe-merintah Daerah sebagai pelaksana otonomi daerah memiliki keterbatasan wewenang dalam mengimpementasikan pengelolaan pajak daerah sebagai sumber Pendapatan Asli Daerah (PAD) dan harus tunduk pada aturan yang sudah diten- tukan oleh Pemerintah Pusat. Kedua, kurangnya kewenangan daerah dalam mengelola pajak daerah terlihat dengan adanya kewajiban evaluasi terhadap perda pajak daerah yang akan dibuat oleh pemerintah daerah.

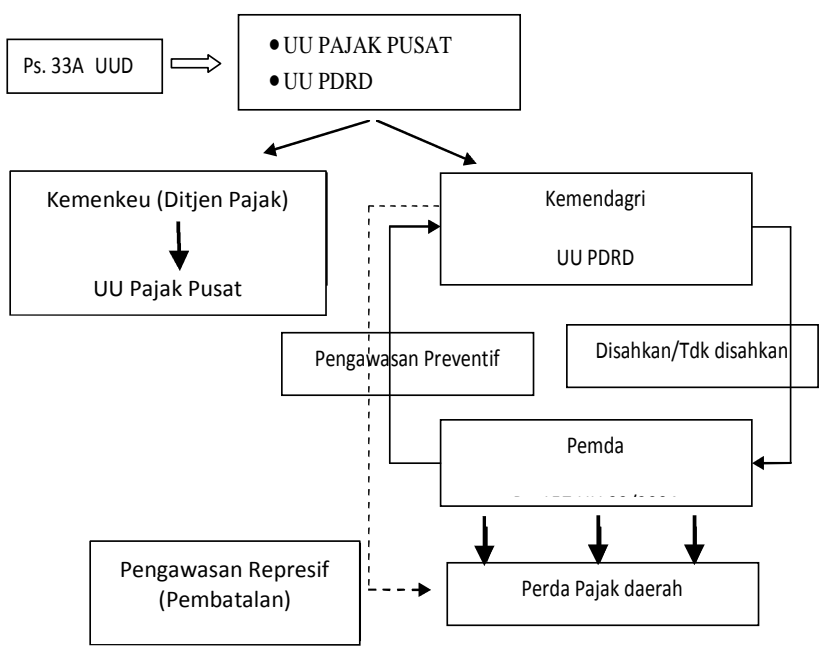

Bagan 1. Alur Pemikiran Kebijakan Pajak Daerah

Ketiga, kebijakan Pengelolaan pajak daerah yang diterapkan oleh Pemerintah Pusat diimplementasikan dalam bentuk kebijakan pengawasan preventif dan represif dan adanya keharusan bagi daerah untuk mengimplementasikan wewenang pengelolaan pajak daerah sesuai dengan arahan dari Pemerintah Pusat mengindikasikan kebijakan pengelolaan pajak daerah belum menunjukan arah kepada pelaksanaan otonomi daerah yang sebenarnya.

\section{Daftar Pustaka}

Bawazier, Fuad. "Reformasi Pajak di Indonesia". Jurnal Legislasi Indonesia, Vol. 8, No. 1 April 2011. Jakarta: Kemenkumham Rl;

Durumurti, Krishna D. "Hukum Pajak atau Hukum dan Pajak, Refleksi Hukum", Jurnal Ilmu Hukum, Edisi Oktober 2010. Salatiga: Fakultas Hukum UKSW;

Emanuel, Victor. "Kewenangan Judikatif Dalam Pengujian Peraturan Kebijakan". Jurnal Yudisial, Vol.6 No. 1 April 2013. Jakarta: Komisi Yudisial;

Fatkhurohman. "Implikasi Pembatalan Perda terhadap Ketepan Proporsi Teori Penegakan Hukum dalam Sistem Peradilan di Indonesia”, Jumal Dinamika Hukum, Vol.13 
No. 1 Januari 2013. Purwokerto: Fakultas Hukum Unsoed;

Hadjon, Philipus M. 1997. Pengantar Hukum Administrasi Negara. Yogyakarta: UGM Press;

Hamidi, Jazim. “Paradigma Baru Pembentukan dan Analisis Peraturan Daerah (Studi Atas Perda Peloyanan Publik dan Perda Keterbukaan Informasi Publik"). Jurnal Hukum, Vol. 18 No. 3 Juli 2011. Malang: Fakultas Hukum Unibraw;

Hartini, Sri dan Setiadjeng Kadarsih. "Analisis Terhadap Implementasi Kebijakan Pengelolaan Jalan di Kabupaten Banyumas". Jurnal Dinamika Hukum, Vol. 12, No. 2, Mei 2012. Purwokerto: FH Unsoed;

Kastro, Edy. "Hubungan Kausalitas Antara Politik dan Hukum". Jurnal Hukum, Vol. VII. No. 1, Edisi Januari 2009. Palembang: PPS Universitas Sriwijaya;

Mardiasmo. 2002. Perpajakan. Edisi Revisi. Yogyakarta: Penerbit Andi;

Nurmayani. "Implikasi Hukum Peralihan Kewenangan Pemungutan PBB P2 Dari Pusat Kepada Pemerintah Kabupaten/Kota". Praevia Jurnal Ilmu Hukum, Vol. 6 No. 2, JuliDesember 2012. Lampung: FH Unila;

Pamuji, Kadar. "Implikasi Kebijakan Pendaerahan Pengelolaan PBB Setelah Berlakunya UU No. 28 Tahun 2009 Tentang PDRD”. Jurnal Dinamika Hukum, Vol. 11 No. 1, Januari 2011. Purwokerto: FH Unsoed;

Rosyadi, Slamet dan Anwaruddin. "Otonomi Dae-rah \& Upaya Mewujudkan Paradigma Pem-bangunan Berkelanjutan". Jurnal Sosial Ekonomi Humaniora, Vol. 2, No. 1, Mei-Oktober 2008. Purwokerto: Lembaga Penelitian Unsoed;

Soekanto, Soerjono dan Sri Mamudji. 1994. Penelitian Hukum Normatif Suatu Tinjuan Singkat. Jakarta: Rajagrafindo Persada;

Sumantry, Deden. "Reformasi Perpajakan sebagai Perlindungan Hukum yang Seimbang antara Wajib Pajak dengan Fiscus sebagai Pelaksanaan terhadap UU Perpajakan", Jurnal Legislasi Indonesia, Vol. 8 No. 1 April 2011. Jakarta: Kemenkumham RI;

Witono, Banu. "Peranan Pengetahuan Pajak pada Kepatuhan Wajib Pajak". Jurnal Akuntansi dan Keuangan, Vol. 7, No. 2, September 2008. Surabaya: Fakultas Ekonomi Universitas Muhammadiyah. 